\title{
直流低圧火花発光法による銑鉄の発光分光分析
}

\section{On Emission Spectrometric Analysis of Pig Iron by using Triggered Capacitor Discharge Source}

Yoshihide Endo, Yasuharu MAtsumura, and Takashi Suginara

\begin{abstract}
Synopsis :
On emission spectrometric analysis of pig iron by using a triggered capacitor discharge source, the influence of precipitated graphite on an analytical result and its prevention were investigated. The followings were obtained.

The abnormal emission on the analysis of pig iron was caused by the preferential discharge to precipitated graphite. This preferential discharge was similar to that caused by non-metallic inclusions in steel. The preferential discharge was improved by the rapid formation of spark hardened layer, which was achieved by the prolonged preburn time or the discharge with high energyspark. The pulse height distribution analysis method was also effective for the elimination of abnormal emission. Consequently, pig iron could be analysed rapidly with a triggered capacitor discharge source, and the analytical precision and accuracy were comparable to those with a high voltage spark source.
\end{abstract}

\section{1. 緒言}

発光分光法で銑鉄を分析するとき，通常は発光源に直 流高圧火花発生装置(以下 HVS と略記する) が用いられ ている.これは直流低圧火花発光法（以下 LVS と略記 する）で放電エネルギーが小さいため，試料の蒸発気 化が十分でなく，採取試料の白銑化の状態によつて発光 強度が異なるなど試料履歴の影響を受けやすく，良好な 分析精度が得られないことによる.しかしながら HVS は断続スパークのため, 単位時間当たりの放電回数増加 には限度があり LVS にみられるよらな高速発光による 分析時間の短縮は困難である.

著者らは銑鉄分析の迅速化を目的として LVS 励起法 の適用を研究した，LVS による銑鉄分析で精度低下の 主因となるのは析出グラファイトである。これについて はすでに報告されており，析出グラファイトへの選択放 電に起因する異常発光であると述べられている(1)2).これ は著者らが先に報告 ${ }^{3)} し た$ 鋼中非金属介在物への選択放 電によるものと類似している。

この析出グラファイトによる異常発光は予備放電時間 の延長ならびに最近その有効性が評価されているパルス 分布測定法 (Pulse Height Distribution Analysis, 以下
PDA と略記する）の適用などにより軽減できることを 明らかにし，さらにはェネルギー容量の大きいアークラ イクな LVS の適用によつても HVS と遜色のない結果 が得られた。

これらのことから LVS による銑鉄分析は十分実用に 供し得ることが明らかになり，分析の迅速化とともに同 一の LVS 発光源で鋼および 銑鉄の分析が 可能となつ たままた LVS の採用により HVS に比べて対電極の使 用回数を著しく増加できる副次効果を生じた.

\section{2. 実 験 方 法}

\section{$2 \cdot 1$ 装}

発光分光分析装置は島津製作所製 LVS-GVM 100 打 よび HVS-GV 200 の二種類を用いた，前者は既報) で 使用した装置で LVS-SG 400 およびェネルギー容量の 大きい LVS-SG 200 の発光源に切り換兄可能で RE11 測光装置 (PDA 処理機構) を付帯している.

これらの装置の励起条件 おっび測定条件を Table 1 に示す。また測定データの処理は島津製作所製小型電算 機 QT-630 システムによつた.

\section{$2 \cdot 2$ 試料調製}

水冷銅定盤を用いて Fig. 1 亿示した銑鉄のスタンプ

炤和 55 年 10 月本会講演大会にて発表 昭和 56 年 1 月 23 日受付 (Received Jan. 23，1981)

* 川猗製鉄 (株) 水舁製鉄所 工博 (Mizushima Works, Kawasaki Steel Corp.)

*2 川崎製鉄 (株) 水息製鉄所 (Mizushima Works, Kawasaki Steel Corp., 1 Mizushimakawasakidori Kurashiki 712) 
Table 1. Instrument and operating parameters.

\begin{tabular}{|c|c|c|c|c|}
\hline \multicolumn{5}{|c|}{$\begin{array}{l}\text { Spectrometer: Shimadzu vacuum quantorecorder } \\
\text { GVM-100 and GV-200 }\end{array}$} \\
\hline \multicolumn{5}{|c|}{ Operating parameters } \\
\hline Excitation sources & : & $\mathrm{SG}-400^{*}$ & $\mathrm{SG}-200^{*}$ & HVS \\
\hline Inductance & $(\mu \mathrm{H}):$ & 3 & 150 & 50200 \\
\hline Capacitance & $(\mu \mathrm{F}):$ & 5 & 15 & $\ddot{i}$ \\
\hline Discharge per s & : & 400 & 200 & 120 \\
\hline Peak potential & $(V):$ & 420 & 420 & 18000 \\
\hline Peak current & (A): & 180 & 320 & - \\
\hline Duration & $(\mu \mathrm{s}):$ & 60 & 250 & - \\
\hline \multicolumn{5}{|l|}{ Burning (Ar : $15 l / \mathrm{min}$ ) } \\
\hline Preburn time & $(\mathrm{s}):$ & 20 & 10 & 100 \\
\hline Integration time & $(\mathrm{s}):$ & $7 \pm 1$ & $10 \pm 1$ & $18 \pm 3$ \\
\hline
\end{tabular}

*: Triggered capacitor discharge source unit.

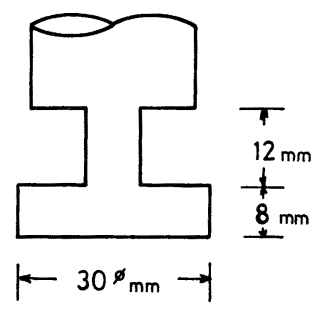

Fig. 1. Shape of cast sample.

Table 2. Chemical composition of typical specimens.

\begin{tabular}{cccccccc}
\hline \multicolumn{7}{c}{ Chemical composition } & $(\%)$ \\
\hline $\mathrm{C}$ & $\mathrm{Si}$ & $\mathrm{Mn}$ & $\mathrm{P}$ & $\mathrm{S}$ & $\mathrm{Ti}$ & $\mathrm{Cr}$ & $\begin{array}{l}\text { Graphite } \\
\text { carbon }\end{array}$ \\
4.61 & 0.48 & 0.43 & 0.096 & 0.030 & 0.21 & 0.02 & 1.43 \\
4.78 & 0.64 & 0.51 & 0.101 & 0.005 & 0.36 & 0.03 & 1.64 \\
4.39 & 0.28 & 0.36 & 0.068 & 0.025 & - & - & 0.38 \\
4.36 & 0.52 & 0.46 & 0.098 & 0.026 & 0.29 & 0.02 & 0.10 \\
4.55 & 0.79 & 0.56 & 0.088 & 0.039 & 0.16 & 0.02 & 0.95 \\
4.66 & 0.36 & 0.43 & 0.115 & 0.006 & 0.39 & 0.03 & 0.97 \\
4.85 & 0.45 & 0.57 & 0.086 & 0.039 & 0.18 & 0.02 & 1.82 \\
4.69 & 0.79 & 0.36 & 0.129 & 0.026 & 0.25 & - & 1.50 \\
\hline
\end{tabular}

試料を採取し供試料とした. 発光面は試料底部とし, 砥 石で約 $1 \mathrm{~mm}$ 研削後ベルト研磨した. 試料の組成は発光 面から切削試料を採取し, 化学分析法により定量した. その代表例を Table 2 に示す.

\section{$2 \cdot 3$ 実験方法}

白銑化試料と白銑化の不完全な試料を発光分光法によ り分析し, 白銑化試料の発光強度を基準として両者の発 光強度差を目的元素に対する影響量とした. さらに両方 の試料について $I-t$ 曲線を求め, その相違点を調べた. 発光面の表面組織は光学顕微鏡あるいは EPMA を用い て観察した.

\section{3. 実験および考察}

\section{$3 \cdot 1$ 析出グラファイトの影響}

LVS を用いる発光分光法で 銑鉄を分析するとき，析

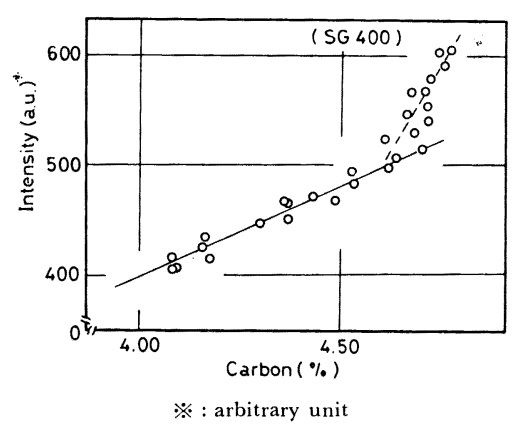

Fig. 2. Calibration curve for carbon.

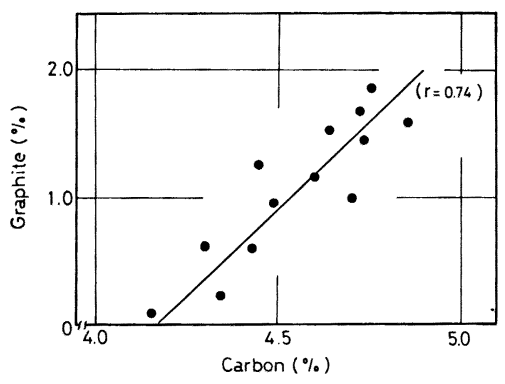

Fig. 3. Relation between contents of graphite and carbon in samples under same condition.

出グラファイトが発光強度に影響を及ぼすことについて は，すでに成田らの報告1)がある，それによると析出グ ラファイト周辺に誘起される選択放電のため放電ストリ ーマーが分散して異常発光となり, 定量值に影響を与え ると述べている.

著者らの追試確認に拉いても Fig. 2 に示すように LVS-SG 400 の励起条件ではG濃度が約 $4.6 \%$ 以上に なると発光強度は異常に高くなり， $\mathrm{C}$ 濃度と発光強度と の比例性が悪くなる. 同一条件で試料を鋳込んだときの グラファイト量と G 濃度との関係を Fig. 3 に示す. 当 然のことながら G濃度の増加とともにグラファイト量も 増大寸る. Fig. 2 に打ける $\mathbf{C}$ 検量線の屈折点 ( C 濃度 $4.6 \%$ でこのときのグラファイト量は約 $0.8 \%$ ）は必ら ずしも普遍的なものではなく, 試料採取条件, 白銑化促 進剂の添加によつても異なることが予想される.

ここでグラファイトの定量は発光面より約 $2 \mathrm{~g}$ のブ ロック試料を切り出し, JIS ${ }^{5)}$ の遊離炭素定量法に準拠し て処理した.

次に Fig. 2 の検量線より求めた定量值と化学分析值 との差 $\Delta C$ とグラファイト量との関係を Fig. 4 に示 す。図より明らかなように $\Delta C$ はグラファイト量の増 加とともに増大している. Fig. 5 は $\mathrm{S}$ 定量におけるグ 


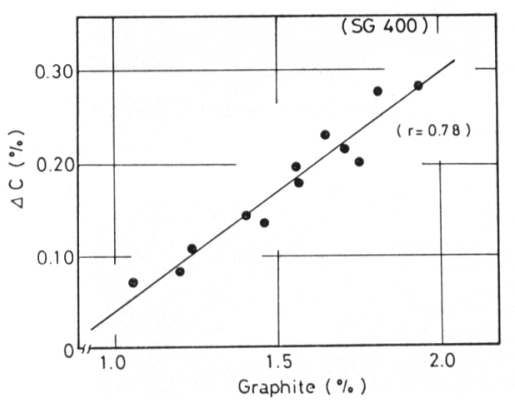

Fig. 4. Influence of graphite content on carbon determination.

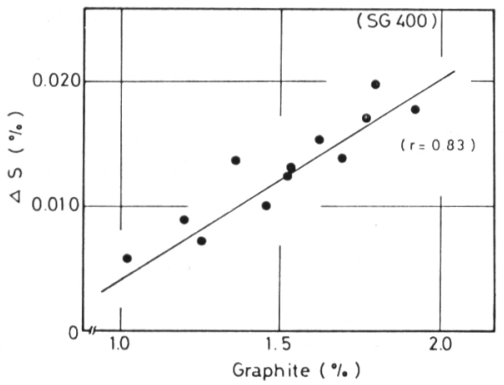

Fig. 5. Influence of graphite content on sulfur determination.

ラファイト量の影響を示したもので， C と同様グラファ イト量の増加とともにその影響が顕著にあらわれてい

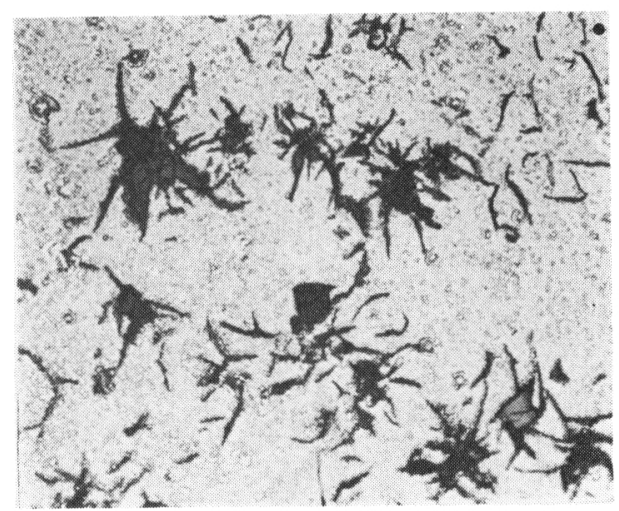

C ; $4.78 \%$, Graphite : $1.80 \%$

Photo. 1. Micrograph of discharge spots on specimen.

$$
\left(\times 400 \times \frac{5}{8}\right)
$$

る.

Photo. 1 はグラファイトの多い試料の発光面を顕微 鏡観察したもので放電跡がラ゙ラファイト周辺に集中して いるが, Photo. 2 のよらにグラファイトの少ない試料で は放電跡が一様に分布していることがわかる，これらの 現象は前述した成田らの報告と一致する。

\section{$3 \cdot 2$ グラファイトの影響除去}

(1) $I-t$ 曲線の観察

Fig. 6 は銑鉄としてはC含有量の多い試料 $(\mathrm{C}: 4.78$
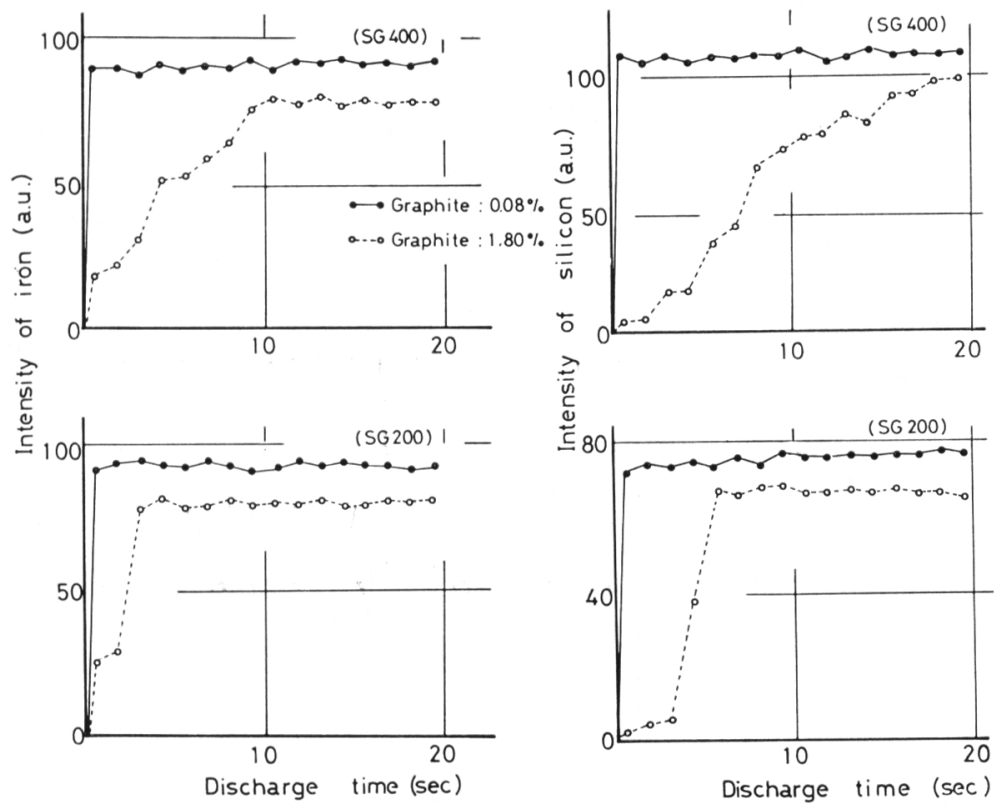

Fig. 6. Intensity-time curves of iron and silicon. 


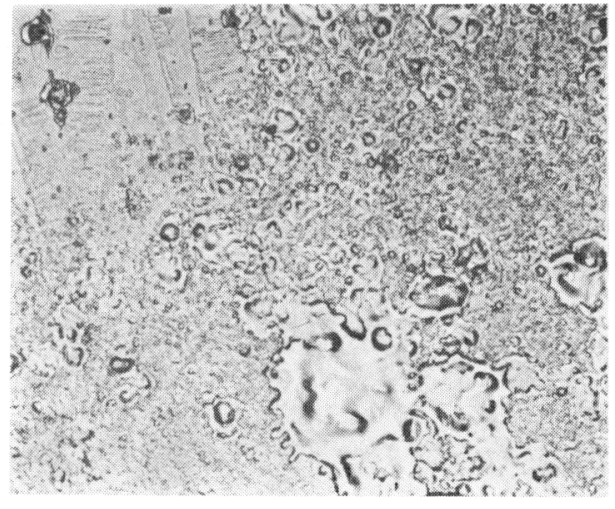

C: $4.36 \%$, Graphite : $0.08 \%$

Photo. 2. Micrograph of discharge spots on specimen.

$$
\left(\times 400 \times \frac{5}{8}\right)
$$

$\%$ グラファイト：1.80\%) と少ない試料（C: 4.35

$\%, ク ゙ ラ フ ァ イ ト: 0.08 \%)$ の $\mathrm{Fe}, \mathrm{Si}$ にいて SG

400 と SG 200 を用いた場合の発光強度と放電時間と の関係 $(I-t$ 曲線) を示したものである。この図からグ ラファイトの多い試料は少ない試料と比較して，放電初 期に拈ける発光強度の立ちあがりが緩やかで, しかも発 光強度が安定するまでの時間も長いことがわかる．例克 ば Si ではグラファイトの少ない試料が約 $2 \mathrm{~s}$ で安定す るのに対してグラファイトの多い試料では 10 数 $\mathrm{s}$ を要 している.これは内部標準の Feについても同じことが いえる，安定になるまでの時間は，SG 200 が SG 400 と比較して短い.

発光分光分析の積分法には定時間法と内部標準法があ り，一般には後者が用いられている．そのため内部標準

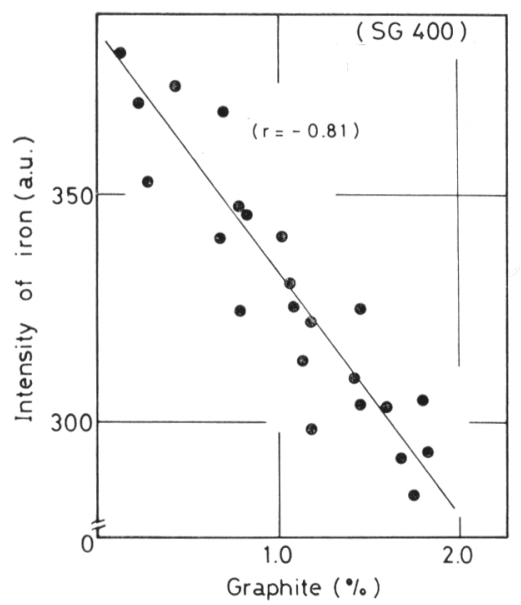

Fig. 7. Relation between graphite content and intensity of iron.

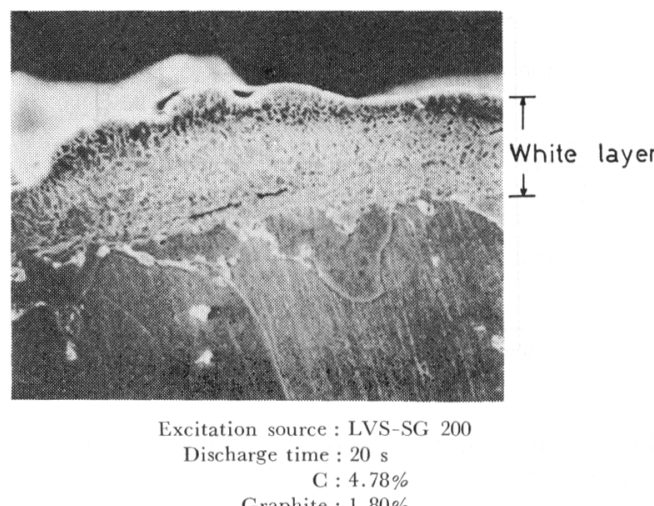

Graphite : $1.80 \%$

Photo. 3. Microstructure of white layer. (section)

$$
\left(\times 2000 \times \frac{3}{5}\right)
$$

Table 3. Effect of preburn time on analytical precision and accuracy of sulfur and silicon.

\begin{tabular}{|c|c|c|c|c|c|c|}
\hline \multirow{2}{*}{ Element } & \multirow{2}{*}{$\begin{array}{l}\text { Standard } \\
\text { deviation }\end{array}$} & \multicolumn{5}{|c|}{ Preburn time (s)* } \\
\hline & & 0 & 5 & 10 & 15 & 20 \\
\hline \multirow{2}{*}{$\mathrm{S}$} & $\sigma$ & 0.0068 & 0.0043 & 0.0020 & 0.0019 & 0.0016 \\
\hline & $\sigma_{\mathrm{d}} * *$ & 0.0075 & 0.0069 & 0.0049 & 0.0020 & 0.0022 \\
\hline \multirow{2}{*}{$\mathrm{Si}$} & $\sigma$ & 0.086 & 0.072 & 0.050 & 0.039 & 0.033 \\
\hline & $\sigma_{\mathrm{d}}$ & 0.101 & 0.079 & 0.043 & 0.040 & 0.041 \\
\hline \multicolumn{7}{|c|}{$*:$ Using $\mathrm{SG}-400$} \\
\hline$* *: \sigma_{\mathrm{d}}=\sqrt{ }$ & \multicolumn{6}{|c|}{$\frac{\sum d^{2}-\left(\sum d\right)^{2} / n}{n-1}, d:$ Difference between standard } \\
\hline
\end{tabular}

$(\%, n=10)$

元素の発光強度の変動が目的元素の定量結果に大きな影 響を与えるのはいうまでもない。

Fig. 7 は $\mathrm{Fe}$ の発光強度とグラファイト量との関係 を示したもので, グラファイトの増加に伴つて Fe の発 光強度が低下している，これはグラファイトの多い試料 では Fe 内部標準法の適用が困難なことを示している。

しかし $I-t$ 曲線からも明らかなように, グラファイト の影響は予備放電時間の延長によつて軽減することがで きる. これは放電時間の増加により Photo. 3 に示す放 電硬化層 (白色層) ${ }^{6}$ が形成され，放電ストリーマーが安 定するためと考劣られる。

Table 3 には Si 拈よび $\mathrm{S}$ を例に予備放電の効果を 示した。表から明らかなように予備放電時間の増加と之 もに分析精度および正確さが向上する。

\section{(2) PDA 法の適用}

グラファイトが目的元素の発光強度に少なからぬ影響 を与えることはすでに述べた。したがつて各放電ごとの 発光強度を測定し，その中に打ける異常発光を除去すれ ば精度の向上が期待できる。本実験に用いた装置は放電 ごとの発光強度をパルス変換し，発光強度を任意に取捨 
Table 4. Effect of integral measurment on analy tical precision by Pulse Height Distribution Analysis method.

$(\%, n=10)$

\begin{tabular}{|c|c|c|c|c|c|}
\hline \multirow{4}{*}{$\begin{array}{l}\text { Ele- } \\
\text { ment }\end{array}$} & \multirow{4}{*}{$\begin{array}{l}\text { Constant } \\
\text { integration } \\
\text { time method }\end{array}$} & \multirow{2}{*}{\multicolumn{4}{|c|}{$\begin{array}{l}\text { Standard deviation* } \\
\text { Internal standard method }\end{array}$}} \\
\hline & & & & & \\
\hline & & \multicolumn{2}{|c|}{$\sum I_{\mathrm{i}} / \sum I_{\mathrm{Fe}}{ }^{* *}$} & \multicolumn{2}{|c|}{$\Sigma\left(I_{\mathrm{i}} / I_{\mathrm{Fe}}\right)$} \\
\hline & & Fe $2714 \AA$ & Fe $2874 \AA$ & Fe $2714 \AA$ & Fe $2874 \AA$ \\
\hline $\mathrm{Si}$ & 0.040 & 0.035 & 0.043 & 0.029 & 0.007 \\
\hline $\mathrm{Mn}$ & 0.009 & 0.006 & 0.007 & 0.007 & 0.006 \\
\hline $\mathrm{P}$ & 0.0051 & 0.0030 & 0.0035 & 0.0032 & 0.0048 \\
\hline $\mathrm{s}$ & 0.0045 & 0.0050 & 0.0039 & 0.0059 & 0.0044 \\
\hline $\mathrm{Ti}$ & 0.045 & 0.020 & 0.027 & 0.009 & 0.041 \\
\hline $\mathrm{Cr}$ & 0.008 & 0.006 & 0.007 & 0.007 & 0.007 \\
\hline
\end{tabular}

選択できる機構（以下 PDA と略記）を有している. そこで $\mathrm{Fe}$ (II) $2714.4 \AA$ と $\mathrm{Fe}(\mathrm{I}) 2874.2 \AA$ の二種類 を内部標準とし PDA 法を用いて全積分法 $\left(\Sigma I_{\mathrm{i}} / \Sigma I_{\mathrm{Fe}}\right)$ と比積分法 $\left[\Sigma\left(I_{\mathrm{i}} / I_{\mathrm{Fe}}\right)\right]$ で銑鉄を分析した. また比較 のため定時間積分法 $\left(\Sigma I_{\mathrm{i}}\right)$ でも実験した。

ここで $I_{\mathrm{i}}$ は目的元素の, $I_{\mathrm{Fe}}$ は $\mathrm{Fe}$ 内部標準の放電 ごとの発光強度を示す.

PDA 法の条件はサンプリング回数を 1000 パルス, 異常パルス除去のためのカットレベルを $\mathrm{Fe}$ 発光強度の 中央值から上下それぞれ $25 \%$ に設定した。

結果は Table 4 に示すように内部標準法は定時間積 分法と比較して分析精度がすぐれ，また内部標準法のな かでも放電ごとに Fe のパルスで除する比積分法が全積 分法より精度が向上している. とくに比積分法では $\mathrm{Si}$ に $\mathrm{Fe}(\mathrm{I}) 2874.2 \AA$ を, $\mathrm{Ti} に \mathrm{Fe}(\mathrm{II}) 2714.4 \AA$ を用い ることにより一層の精度向上が認められる.

これらのことから銑鉄分析に対し明らかに PDA 法の 効果が認められ，異常放電カットあるいは目的元素のス ペクトル線に適合する内部標準線の選択によつて分析精 度が向上する。

LVS による銑鉄分析では以上に述べた予備放電時間 の延長，PDA 法の適用などにより良好な結果が得られ た。

（3）放電エネルギーの大きいLVS の適用

これまでの結果は通常の LVS (SG 400) で行なつた ものであり，これによりほぼ実用に供し得る精度が得ら

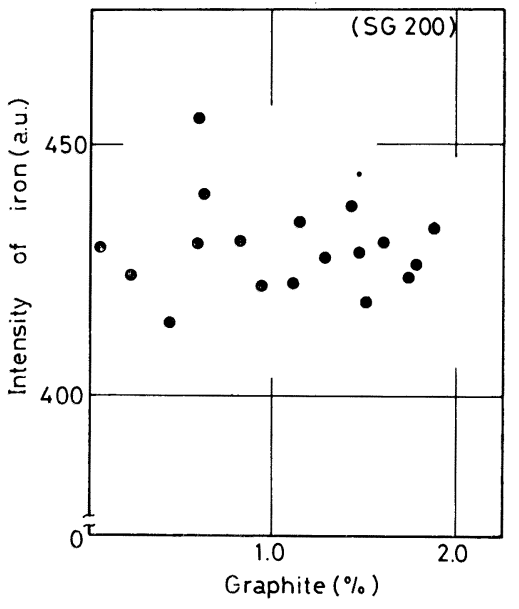

Fig. 8. Relation between graphite content and intensity of iron.

れたが，さらにェネルギーの大きい励起条件を用いれば 安定な放電硬化層（白色層）金）をより早く形成すること が考えられる。すでにこの原理の応用例として硫黄快削 鋼の分析 ${ }^{7) か ゙ あ る . ~}$

そこで Table 1 の条件を設定しグラファイトの影響 を低減することにした。

分析方法は，(a)予備放電を放電エネルギーの大きい SG 200 で積分放電を通常の SG 400 で行う(b) 予備放 電, 積分放電ともに SG 200 で行う，の二方法を用い た. 結果は Table 5 に示すよらに(a)法，(b)法とも に HVS と比較して遜色のない分析精度が得られた。さ らに Fig. 8 に示すよらに Fe の発光強度もグラファイ トの影響を受けていない。しかし(a)法では Si を $1 \%$ 以上含有する試料が $\mathrm{S}$ 定量時に異常值を生じる場合があ る. 一方 $(\mathrm{b})$ 法は銑鉄分析に十分供しうる精度があり, しかも予備放電時間は (a) 法と比較して短くてよく, 分 析所要時間も HVS の $120 \mathrm{~s}$ から $20 \mathrm{~s}$ へと短縮できた。 さらに積分放電終了時に極性を反転し，対電極の付着物 を除去する極性反転装置を LVS 法に付加した。 これに よると，Fig. 9 に SG 200 を用いた時の $\mathrm{Si}$ と S の例 を示したように通常十数回の放電で発光強度が急激に低 下する現象が逆放電によつて軽減され，対電極の使用回 数も数十回に延長できた.

Table 5. Comparison of analytical precision and accuracy.

$(\%, n=10)$

\begin{tabular}{|c|c|c|c|c|c|c|c|c|c|c|}
\hline \multirow{2}{*}{ Method } & & \multicolumn{3}{|c|}{$\begin{array}{l}\text { Preburn: SG-200 } \\
\text { Integration : SG-400 }\end{array}$} & \multicolumn{3}{|c|}{$\begin{array}{l}\text { Preburn : SG-200 } \\
\text { Integration : SG-200 }\end{array}$} & \multicolumn{3}{|c|}{ HVS } \\
\hline & & $\mathrm{Si}$ & $\mathrm{Mn}$ & $\mathrm{S}$ & $\mathrm{Si}$ & $\mathrm{Mn}$ & $\mathrm{S}$ & $\mathrm{Si}$ & $\mathrm{Mn}$ & $\mathrm{S}$ \\
\hline Standard & $\sigma$ & 0.009 & 0.006 & 0.0023 & 0.009 & 0.005 & 0.0016 & 0.008 & 0.005 & 0.0022 \\
\hline deviation & $\sigma_{\mathrm{d}}$ & 0.018 & 0.014 & 0.0051 & 0.016 & 0.011 & 0.0022 & 0.020 & 0.010 & 0.0020 \\
\hline
\end{tabular}



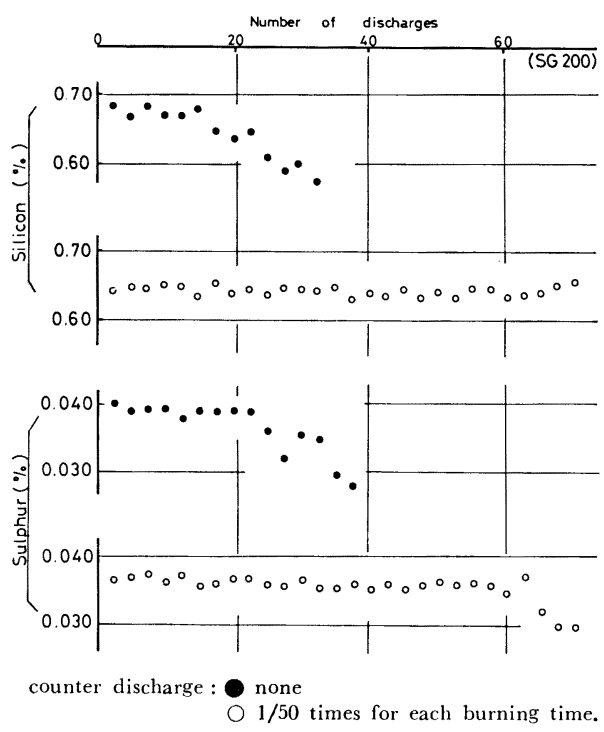

Fig. 9. Effect of counter discharge on analytical results of sulfur and silicon, and life of counter electrode.

この LVS 法は SG 200, SG 400 の二種類の発光条 件を具備しているので同一の装置で銑鉄および鋼の分析 が可能である.

\section{4. 結言}

銑鉄を LVS で分析する場合，析出グラファイトが異 常值の原因となり，これはグラファイトが多い程大き い.この影響および対策について研究し次の知見を得
た.

（1）予備放電時間の延長は安定な放電硬化層（白色 層）の形成に効果があり，この放電硬化層形成によつて グラファイトの影響が低減できる.

（2）PDA 法の適用はグラファイトに起因する異常 発光の除去に効果があり, 精度が向上する. また目的元 素のスペクトル線に適合した Fe 内部標準線の選択によ りその効果が増加する.

（3）エネルギー容量の大きい励起法は放電硬化層の 形成を早めグラファイトの影響をさらに軽減できる. こ の方法は従来の HVS と比較して迅速性があり, から精 度も遜色がない。

すなわち(1)〜(3)の併用により銑鉄が LVS で精度 よく分析することができる．このため鋼，銑鉄ともに同 じ発光源を使用でき，しかも LVS の高速化により迅速 性が著しく増加できる。

\section{文献}

1 ) 成田貴一，松村哲夫，德田利幸，諸岡錬平，野々 村英造：鉄と鋼，60（1974） 13，p. 1879

2 ) 鹿島次郎, 久保田正明：分光研究，19(1970) 2, p. 93

3 ）遠藤芳秀，杉原孝志，松村泰治：鉄と鋼， 66 (1980) 9, p. 1401

4 ）遠藤芳秀，杉原孝志，大迫義彦：鉄と鋼， 66 (1980) 4, S 405

5 ) JIS G1211 (1976)

6 ）鈴木正敏：鉄と鋼，48（1962）1， p. 50

7 ) 柴田 勉, 浜田栄, 奥山祐治, 柏尾義隆, 田中 勇, 佐藤公隆：分析化学，29 (1980) 5, p. 297 